\title{
Early Events of Citrus Greening (Huanglongbing) Disease Development at the Ultrastructural Level
}

\author{
Svetlana Y. Folimonova and Diann S. Achor
}

Citrus Research and Education Center, University of Florida, 700 Experiment Station Road, Lake Alfred 33850. Accepted for publication 27 April 2010.

\begin{abstract}
Folimonova, S. Y., and Achor, D. S. 2010. Early events of citrus greening (Huanglongbing) disease development at the ultrastructural level. Phytopathology 100:949-958.

Citrus greening (Huanglongbing [HLB]) is one of the most destructive diseases of citrus worldwide. The causal agent of HLB in Florida is thought to be 'Candidatus Liberibacter asiaticus'. Understanding of the early events in HLB infection is critical for the development of effective measures to control the disease. In this work, we conducted cytopathological studies by following the development of the disease in citrus trees graft inoculated with ' $\mathrm{Ca}$. L. asiaticus'-containing material under greenhouse conditions to examine the correlation between ultrastructural changes and symptom production, with the main objective of characterizing the early events of infection. Based on our observations, one of the first degenerative changes induced upon invasion of the pathogen appears to be swelling of middle lamella between cell walls surrounding sieve

elements. This anatomical aberration was often observed in samples from newly growing flushes in inoculated sweet orange and grapefruit trees at the early "presymptomatic" stage of HLB infection. Development of symptoms and their progression correlated with an increasing degree of microscopic aberrations. Remarkably, the ability to observe the bacterium in the infected tissue also correlated with the degree of the disease progression. Large numbers of bacterial cells were found in phloem sieve tubes in tissue samples from presymptomatic young flushes. In contrast, we did not observe the bacteria in highly symptomatic leaf samples, suggesting a possibility that, at more advanced stages of the disease, a major proportion of ' $\mathrm{Ca}$. L. asiaticus' is present in a nonviable state. We trust that observations reported here advance our understanding of how ' $C a$. L. asiaticus' causes disease. Furthermore, they may be an important aid in answering a question: when and where within an infected tree the tissue serves as a better inoculum source for acquisition and transmission of the bacterium by its psyllid vector.
\end{abstract}

Citrus greening (Huanglongbing [HLB]) is one of the most destructive diseases of citrus worldwide. The impact of HLB on citrus production has been clearly documented in many different countries, starting first with century-old reports of citrus "dieback" (one of the other common names of the disease) in India and the "yellow shoot" disease in China, which have been followed by multiple reports describing the disease in South Africa, Philippines, Indonesia, Thailand, Brazil, and, most recently, (since 2005) in Florida in the United States (2). Nearly all commercial citrus species are susceptible to HLB. Infected trees develop blotchy-mottled or completely yellow chlorotic leaves, sometimes resembling mineral deficiencies, and produce small, lopsided, bitter-tasting fruit with small and aborted seeds (10). As the disease progresses, tree growth and fruit yield are significantly reduced, making the orchard economically not viable.

Three species of the bacterium that belongs to the genus 'Candidatus Liberibacter'-'Ca. L. asiaticus', 'Ca. L. africanus', and ' $C a$. L. americanus'-have been found to be associated with HLB (2). Additionally, association of two Phytoplasma spp. with HLB symptoms has been demonstrated for disease-affected trees in Brazil and China $(4,26)$. Two psyllid species-Trioza erytreae and Diaphorina citri-are natural vectors of ' $\mathrm{Ca}$. Liberibacter spp.' and are responsible for transmission of the disease from tree to tree.

The causal agent of HLB in Florida is thought to be ' $\mathrm{Ca}$. L. asiaticus', which is supported by positive results of polymerase chain reaction (PCR)-based assays of multiple samples collected

Corresponding author. S. Y. Folimonova; E-mail address: sveta@ crec.ifas.ufl.edu

doi:10.1094/PHYTO-100-9-0949

() 2010 The American Phytopathological Society from various regions throughout the state using ' $\mathrm{Ca}$. L. asiaticus'specific oligonucleotide primers and 16S rRNA gene clone library sequencing $(20,24,25)$. However, because the cultivation of the pathogen and Koch's postulates have not been completed, involvement of other organisms in the disease development cannot be ruled out. HLB was first detected in Florida in the Miami area in 2005 and, since that time, the disease has moved essentially to all citrus-growing areas in Florida and even farther, beyond the state: HLB-infected trees have been found in Louisiana, Georgia, and South Carolina. Overall, HLB represents a major threat to the entire U.S. citrus industry. For this reason, effective methods of early HLB detection, controlling its transmission by psyllids, and developing resistant citrus cultivars that can be produced economically are needed. Understanding how ' $\mathrm{Ca}$. Liberibacter spp.' multiply, move, and cause disease in citrus will provide a necessary foundation for these objectives.

Previous studies of HLB cytopathology conducted with samples collected from severely infected trees in different citrus-growing regions revealed major anatomical aberrations associated with the disease. Light microscopy studies of leaf samples from highly symptomatic sweet orange field trees demonstrated multiple localized pockets of necrotic phloem scattered through the vascular system, massive accumulation of starch in the plastids, aberrations in cambial activity, and excessive phloem formation $(21,22)$. It was suggested that extensive phloem necrosis causes blockage of the translocation stream, which leads to other anatomical changes; together, they are responsible for yellow blotching, leatheriness, vein yellowing, and clearing on leaves of infected trees (22). Examinations of the disease-affected tissues using transmission electron microscopy (TEM) revealed that the pathogenic bacterium possesses a cell wall of the gram-negative type and exclusively resides within the sieve tubes of infected citrus trees $(7,8,13,14)$. These properties of the bacterium were 
used as a basis for the detection of HLB by electron microscopy, which had been the only reliable diagnostic technique for a number of years prior to the development of detection methods based on DNA hybridization and PCR. However, it has been difficult to consistently detect ' $C a$. Liberibacter spp.' because the pathogen is unevenly distributed in host citrus plants and, even in areas where it is present, the number of bacteria per sieve tube is low (2). Most recently, microscopy studies of samples collected from sweet orange trees with characteristic symptoms of HLB in Brazil revealed the presence of wall-less bodies of phytoplasma, while ' $C a$. Liberibacter'-like bacterial cells were absent, thus suggesting that another phloem-restricted organism might have a role in the disease (26). Interestingly, similarly to ' $C a$. Liberibacter spp.' infections, the number of phytoplasma cells found in sieve tubes of those tissues was also very low, which is in contrast with typical phytoplasma infections where large numbers of phytoplasma cells could be seen (26).

Recently, we examined the responses of different genotypes of citrus to HLB under controlled greenhouse conditions (6). These conditions allowed us to monitor progression of the disease symptom development over a period of time starting from the moment of inoculation of trees with the infected material and, most importantly, made possible evaluation of the infection at early stages that practically cannot be accomplished with trees in the field. Earlier studies of HLB anatomical symptoms, discussed above, were conducted using material from field trees severely affected by the disease. In this work, we examined ultrastructural changes in citrus plants graft inoculated with ' $\mathrm{Ca}$. L. asiaticus'infected budwood at different stages of infection, with the main interest to characterize early events of infection. Here, we show the progression of anatomical aberrations occurring at each stage of the HLB disease and how those aberrations correlated with the development of symptoms. Remarkably, the ability to observe the bacterium in the infected tissue also correlated with the degree of the disease progression.

\section{MATERIALS AND METHODS}

Plant materials, inoculations, and plant growing conditions. Citrus germplasm was obtained from the FDACS Division of Plant Industry (DPI) or United States Department of Agriculture (USDA) Agricultural Research Service National Clonal Germplasm Repository for Citrus and Dates (CRC). HLB inoculum was initially collected from symptomatic field trees located in a grove in Highlands County, FL. The inoculum source was verified to have ' $C a$. L. asiaticus' via real-time quantitative (q)PCR assays with the pathogen-specific primers in our previous study (6) and was also tested for the presence of phytoplasmas, which gave negative results (J. Chen, personal communication). The inoculum was further propagated by grafting into Madam Vinous sweet orange (Citrus sinensis (L.) Osbeck) trees grown in the greenhouse and verified by PCR. For the experiments described in this work, 8-month-old seedlings of Madam Vinous and Pineapple sweet orange (15 and 5 seedlings, respectively) and Duncan grapefruit ( $C$. paradisi Mac Fadyen, 15 seedlings) were used for inoculation with ' $\mathrm{Ca}$. L. asiaticus'-infected budwood. Plants of each variety were graft inoculated with three pieces of budwood from PCR-positive HLB source trees propagated in the greenhouse. Inoculated plants were kept in a USDA Animal and Plant Health Inspection Service approved secure greenhouse with the temperature of 26 to $32^{\circ} \mathrm{C}$ along with uninoculated healthy control plants (six plants of each cultivar). Two weeks after grafting, the plants were trimmed back to stimulate the development of new growth. Visual observation of symptoms along with PCR assays using ' $\mathrm{Ca}$. L. asiaticus'-specific primers (described below) were performed at different time points starting 1 month after inoculation and continued for 1 year. Those plants that became PCR positive for ' $\mathrm{Ca}$. L. asiaticus' and developed an infection $(\approx 70 \%$ of plants that were graft inoculated) were further monitored and sampled for TEM observations as discussed below.

PCR assays. Samples of leaf midrib tissue were used for DNA isolation according to the procedure described by Folimonova et al. (6). In brief, leaf midrib tissue $(250 \mathrm{mg})$ was extracted in $2.5 \mathrm{ml}$ of extraction buffer (100 mM Tris-HCL, $\mathrm{pH} 8.0 ; 50 \mathrm{mM}$ EDTA; $500 \mathrm{mM} \mathrm{NaCl}$; and $10 \mathrm{mM}$ dithiothreitol). A portion of the extract $(1,300 \mu \mathrm{l})$ was transferred to a 2-ml Eppendorf tube, $90 \mu \mathrm{l}$ of $20 \%$ sodium dodecyl sulfate was added, and the mixture was incubated at $65^{\circ} \mathrm{C}$ for $30 \mathrm{~min}$. Following incubation, $500 \mu \mathrm{l}$ of $5 \mathrm{M}$ potassium acetate was added, mixed thoroughly, and incubated on ice for $20 \mathrm{~min}$. The mixture was centrifuged at $13,000 \mathrm{rpm}$ for $10 \mathrm{~min}, 400 \mu \mathrm{l}$ of supernatant was recovered, and DNA was precipitated by adding an equal volume of isopropanol and held at $-20^{\circ} \mathrm{C}$ overnight. The DNA was pelleted, washed, and resuspended in $100 \mu \mathrm{l}$ of water for PCR analysis. qPCR tests were performed as described previously (25). qPCR reactions were carried out using primer-probe sets HLBaspr plus a plant cytochrome oxidase (COX)-based primer-probe set (COXfpr) as indicated in $\mathrm{Li}$ et al. (15). All reactions were done in triplicate with positive, healthy, and water controls, and the mean value of the threshold cycle $(\mathrm{Ct})$ was analyzed.

Electron microscopy. Microscopy studies were conducted using a Morgagni 268 transmission electron microscope (FEI Company, The Netherlands). For ultrastructural observations, leaf and petiole samples were collected from HLB-inoculated as well as healthy control plants at three consecutive time points $(3,6$, and 9 months after inoculation) and prepared for routine TEM. Numerous sections of tissue samples from 25 ' $\mathrm{Ca}$. L. asiaticus'positive trees of three citrus cultivars were produced along with samples collected from healthy control trees. The first sampling

TABLE 1. Quantitative real-time polymerase chain reaction (qPCR) detection of 'Candidatus Liberibacter asiaticus' in leaves of citrus trees at 3, 6, and 9 months after inoculation ${ }^{\mathrm{a}}$

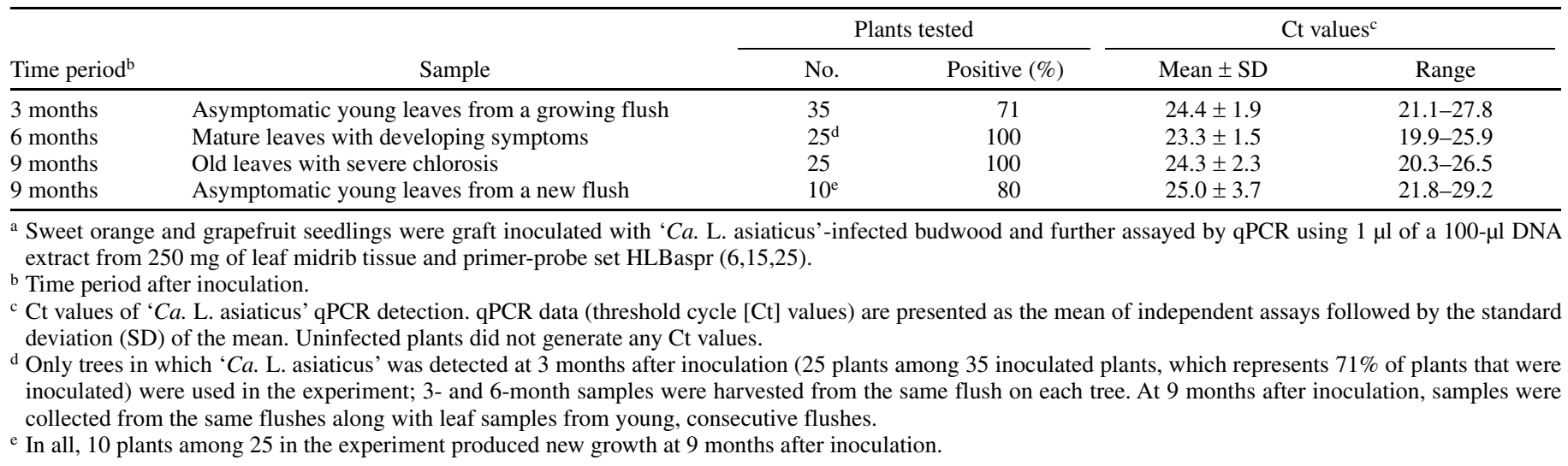


of the inoculated plants occurred at 3 months after graft inoculation of plants. Tissue samples were taken from the young, nearly fully expanded leaves from the growing flush of the inoculated plants. At the time of the first sampling, the inoculated plants were not showing any symptoms. Control samples were collected from comparable flushes of uninoculated trees. At 6 months after inoculation, samples were taken from the same flushes which, by then, were hardened off and had developed some disease-related symptoms. Control samples were collected from comparable flushes of uninoculated trees. By 9 months after inoculation, those flushes produced new growth and, thus, petioles of the old leaves were collected along with samples from the consecutive young, growing flush. Control samples were collected from comparable flushes of uninoculated trees.

To prepare these samples for TEM, a routine fixation procedure was used in which they were fixed with $3 \%$ glutaraldehyde in $0.1 \mathrm{M}$ potassium phosphate buffer, $\mathrm{pH} 7.2$, for $4 \mathrm{~h}$ at room temperature, and then post-fixed in $2 \%$ osmium tetroxide in the same buffer for $4 \mathrm{~h}$ at room temperature. The samples were further washed in the phosphate buffer, dehydrated in a $10 \%$ acetone series, 10 min per step, and infiltrated and embedded in Spurr's resin over 3 days (23). Samples $(1 \mu \mathrm{m})$ were taken for light microscopy observations. Sections of $100 \mathrm{~nm}$ in size were mounted on 200-mesh formvar-coated copper grids and stained with $2 \%$ aq.
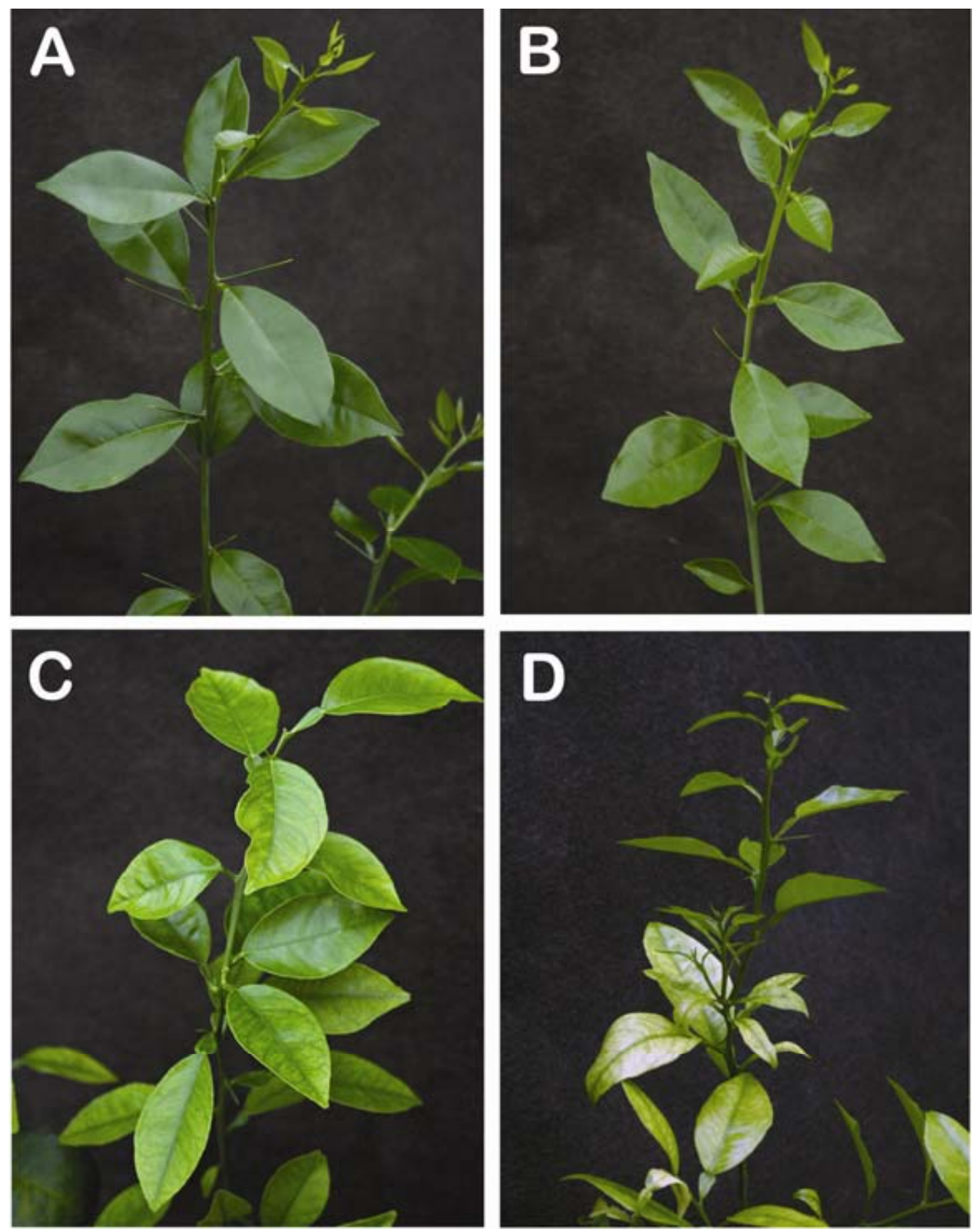

Fig. 1. Progression of Huanglongbing (HLB)-related symptoms in 'Candidatus Liberibacter asiaticus'-inoculated Madam Vinous sweet orange seedling. A, Branch from a control healthy plant; B, young, growing flush from a graft-inoculated plant showing no disease-related symptoms at 3 months after inoculation; C, matured flush from an infected tree with developing symptoms at 6 months after inoculation; D, old flush with severe chlorosis and consecutive, newly growing asymptomatic flush at 9 months after inoculation. 
uranyl acetate and lead citrate (18). The thin sections were further examined with a Morgagni 268 transmission electron microscope.

\section{RESULTS}

Progression of the disease development in graft-inoculated sweet orange and grapefruit trees. Inoculation of small greenhouse trees of sweet orange and grapefruit by grafting HLBinfected buds into the stems of the receptor trees and their further observation over a period of time coupled with PCR assays revealed a timeline of the disease development. Two sweet orange cultivars as well as grapefruit examined in this work demonstrated significant similarity in their response to HLB infection by showing similar progressions of the disease symptoms and highly comparable ultrastructural aberrations at various stages of the disease (discussed below). Thus, here we refer to those cultivars as citrus plants.

At 1 and 2 months after grafting, plants remained asymptomatic and the presence of ' $\mathrm{Ca}$. L. asiaticus' was not detected by qPCR with pathogen-specific primers in any of the plants (data not shown). At $\approx 3$ months after inoculation, ' $C a$. L. asiaticus' amplification was detected in newly growing flushes in $71 \%$ of the inoculated citrus trees; however, none of the plants were showing any disease-related symptoms at that time (Table 1; Fig. $1 \mathrm{~A}$ and B). HLB-characteristic chlorosis began to develop on shoots of those plants within the next couple of months. By 5 to 6 months after grafting, slight yellowing of leaves progressing to more severe asymmetrical yellowing was easily noticeable (Fig. 1C). Symptomatic leaves tested PCR positive for ' $\mathrm{Ca}$. L. asiaticus' (Table 1). Nine months after inoculation, mature sympto-
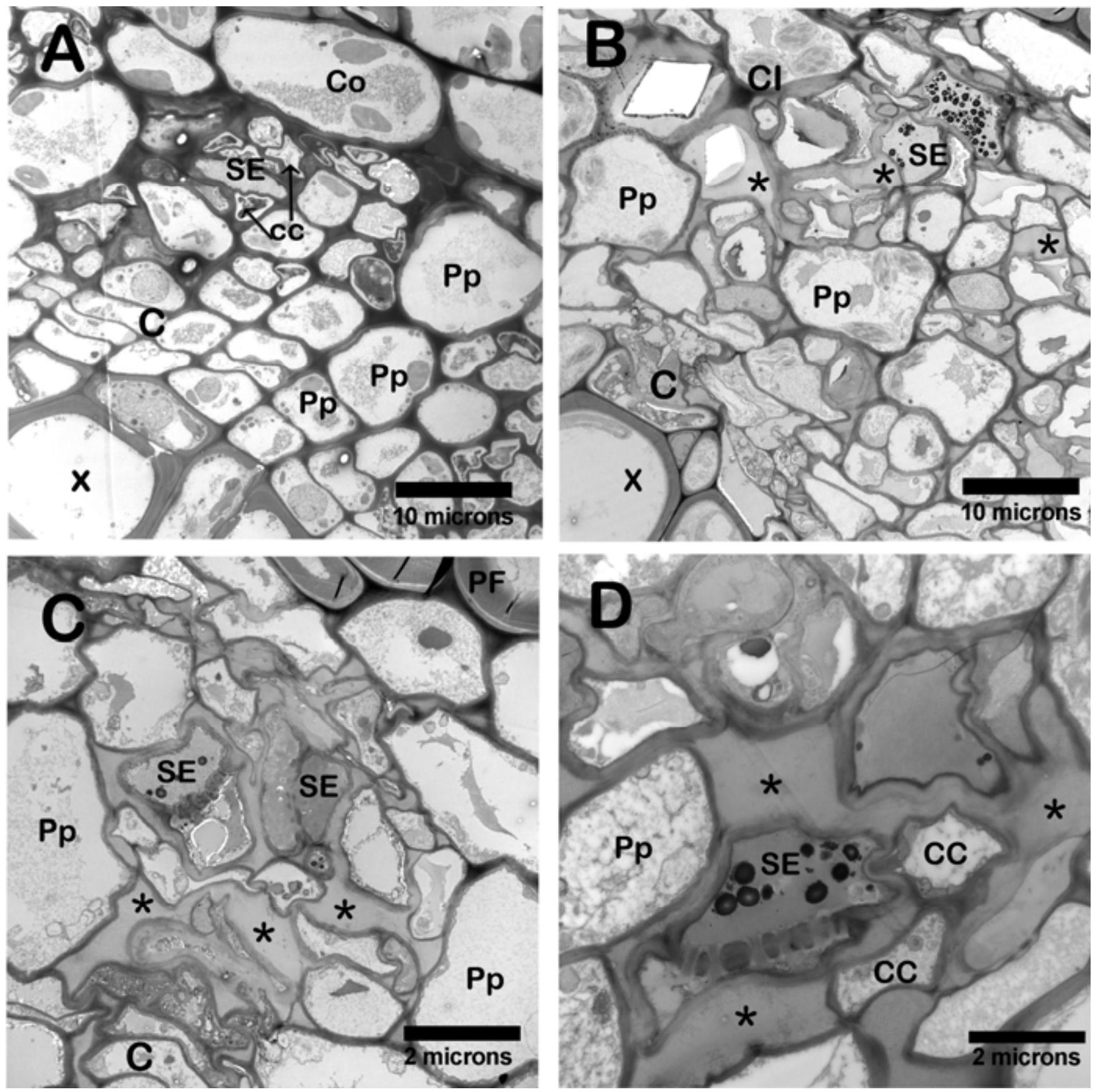

Fig. 2. Transmission electron micrographs of cross-sections of Madam Vinous young leaf petioles illustrating the phloem area of A, healthy plant and $\mathbf{B}$ to $\mathbf{D}$, phloem of 'Candidatus Liberibacter asiaticus'-inoculated plants at 3 months after inoculation. Note dark, round-shaped depositions of starch in sieve elements in B to D. X, xylem; C, cambium layer; Co, cortex; SE, sieve element; CC, companion cells; Pp, phloem parenchyma; CI, crystal idioblast; *, swollen middle lamella. 
matic leaves appeared smaller in size, thickened, and completely yellow or mottled, with some of them showing vein-corking and often easily abscised from the tree (Fig. 1D). Ct values obtained as a result of qPCR tests with samples collected from the same flush on each tree at different time points during the infection process were comparable (Table 1). The infected trees showed significantly reduced growth compared with uninoculated healthy trees. Most of the severely affected branches in $60 \%$ of the infected plants did not produce any additional new growth. The rest of the infected plants $(40 \%$ of the total number of the infected plants) did produce new flushes on which the young leaves were smaller in size and later became chlorotic upon maturity. Most of the infected plants severely declined with time, and some of them eventually died over the next year.

Early ultrastructural changes of phloem tissue in response to HLB infection, "presymptomatic" stage. To study the relationship between symptom expression and anatomical changes, we first examined petioles of nearly fully expanded young leaves collected at 3 months after inoculation from the young growing flushes in which 'Ca. L. asiaticus' was detected, yet leaves remained asymptomatic, along with samples collected from healthy control trees using TEM. Examination of those samples revealed that, despite the fact that no significant phloem disruption occurred in the infected plants at this "presymptomatic" stage, some anatomical aberrations corresponding to the disease began to develop. A cross-section through a healthy leaf petiole is shown in Figure 2A. The phloem tissue extending from the xylem to phloem fibers is highlighted, showing the cambium layer adjacent to the xylem and a sieve element with surrounding companion and phloem parenchyma cells. Thin spaces between the cells are filled with normal amounts of middle lamella components.

The most striking structural change noted in the phloem of leaves from infected trees was significant swelling of the middle lamella between cell walls surrounding sieve elements. This was observed repeatedly during examination of multiple tissue sections (Fig. 2B to D). Moreover, in some instances, sieve elements and companion cells confined within areas with swollen middle lamella appeared to show signs of compression. (Fig. 2C and D). Further examination of sieve elements from infected leaves showed that most of them had a relatively small amount of callose lining the sieve element pores, similarly to sieve elements of healthy phloem tissue (Fig. 3A and B). However, a few sieve elements found in samples from the infected trees contained more extensive deposits of amorphous callose (Fig. 3C). Often, sieve elements in diseased tissue as well as in tissue from control healthy plants also contained dark, round depositions of starch (Figs. 2B and D and 3B) that made sieve elements easy to recognize in the absence of an obvious sieve plate. No starch accumulation was found in phloem parenchyma cells. Tissue from infected plants showed no phloem necrosis as well as no aberrations at the cambium layer (Fig. 2B).

Further observations of the infected tissue revealed the presence of a large number of bacteria-like cells of a pleomorphic shape in several sieve elements (Fig. 4A to C). Examination of their structure with higher magnification revealed double membranes surrounding cells (Fig. 4D), a structural feature that allows differentiation between bacteria and phytoplasma organisms. Those bacteria were present in two different forms (filamentous and round forms), with a diameter of 0.13 to $0.43 \mu \mathrm{m}$, which is one of the characteristics of the morphology of the HLB organism previously described in TEM observations of samples from infected citrus trees as well as periwinkles $(3,8)$. In some sieve cells, the bacteria were embedded in a fibril-like material of unknown origin (Fig. 4A to D). As expected, the bacteria were restricted to phloem sieve tubes.

Anatomical aberrations in phloem tissue at the more advanced stages of HLB infection. TEM observations of phloem tissue of leaf petioles collected from mature symptomatic flush at
6 months after plant inoculation demonstrated significant anatomical changes in the phloem structure compared with samples from healthy control trees. Most sieve elements and companion cells and, occasionally, cambium cells were collapsed (Fig. 5).
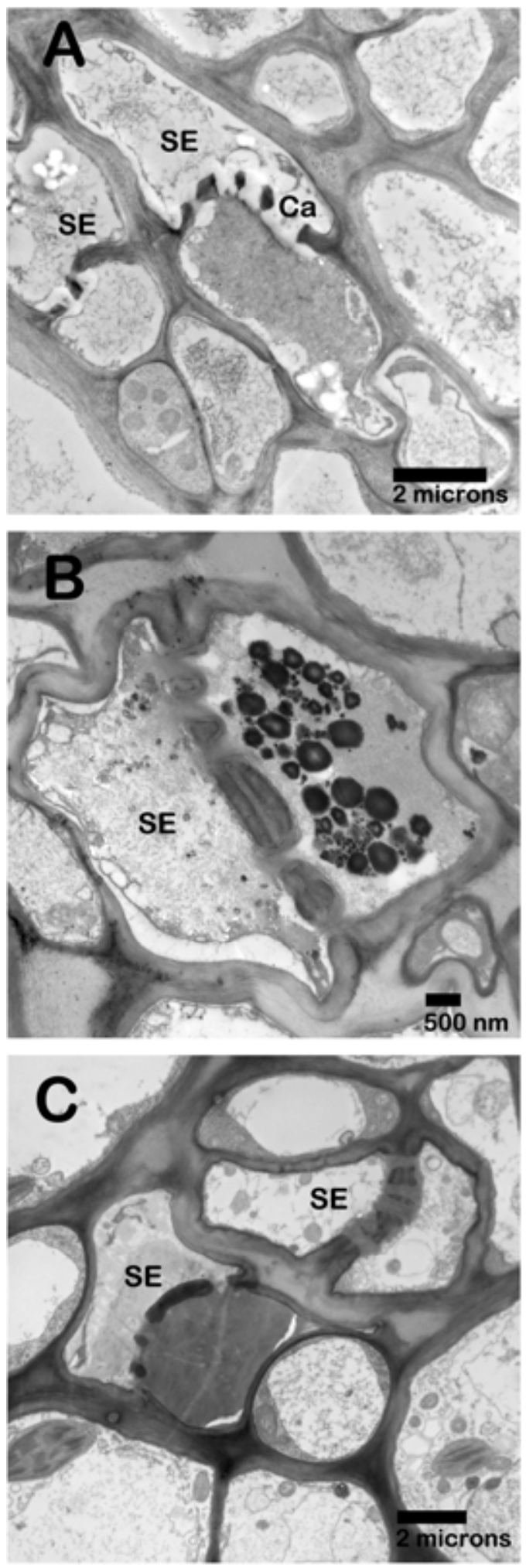

Fig. 3. Transmission electron microscopy of sieve elements (SE) from leaf petioles of A, healthy Madam Vinous and $\mathbf{B}$ and $\mathbf{C}$, 'Candidatus Liberibacter asiaticus'-inoculated Madam Vinous at 3 months after inoculation. Note presence of minimal amounts of callose $(\mathrm{Ca})$ in a healthy sieve element. Sieve element in $\mathbf{B}$ shows callose-free sieve plate. Sieve element in $\mathrm{C}$ is plugged with a P-protein-like material. Note dark, round-shaped depositions of starch in sieve elements in $\mathbf{B}$. 
Sieve pores of those sieve elements that were not necrotic were plugged with the callose-like and p-protein-like material (Figs. 5C and $6 \mathrm{~A}$ and $\mathrm{B}$ ). Phloem parenchyma cells were not collapsed yet were significantly expanded in size, and many of those cells contained large, prominent nuclei and enriched cytoplasm (Fig. 5B) compared with cells in the control tissue (Fig. 5A). The increased size and number of those cells possibly could account for the overall enlargement of the phloem layer in the diseased leaves. No extensive amount of starch accumulation was noted in the phloem parenchyma at this stage of infection (Fig. 4B and C). All of those changes occurred over a period of 3 months and were apparently correlated with the progression of the disease symptoms. Remarkably, all repeatedly examined sections did not show bacteria.

Further examination of tissue samples collected from the same matured flushes 9 months after inoculation demonstrated pro- gressively increasing severity of ultrastructural aberrations of the infected phloem compared with samples from healthy trees and appeared to be correlated with the disease development. Healthy phloem adjacent to the xylem, with normal-looking cambium layer, sieve elements, companion cells, and phloem parenchyma, is shown in Figure 7A. The older layer of healthy phloem near the phloem fibers contained somewhat enlarged phloem parenchyma cells with large vacuoles and sparse cytoplasm but almost no starch (Fig. 7B). Samples from HLB-infected, highly symptomatic old leaves showed almost total collapse of the newest phloem cells close to the xylem, making identification of individual cells difficult (Fig. 7C). The older, outer phloem showed excessive accumulation of starch in the parenchyma cells and collapse of other types of phloem cells, presumably sieve elements and companion cells, located between the paren-
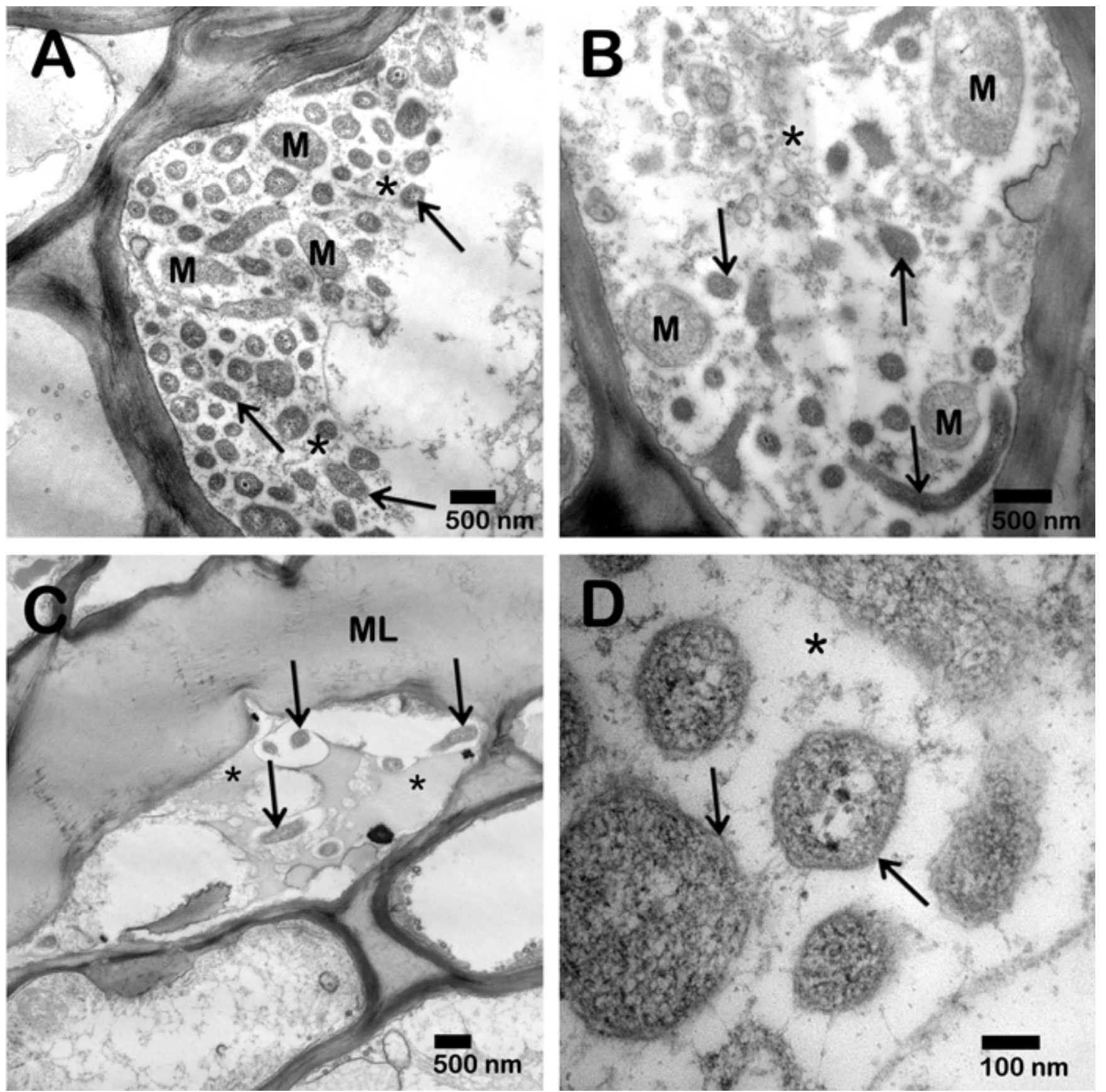

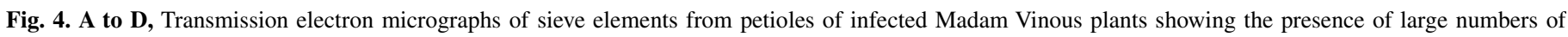

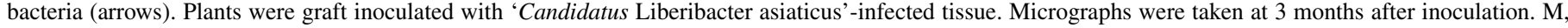

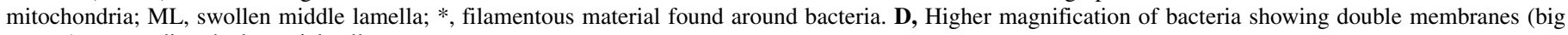
arrows) surrounding the bacterial cells. 
chyma cells (Fig. 7D). No bacterial cells were observed in these tissues.

Examination of phloem tissue in the new growth produced on HLB-infected trees at the later stage of disease develop-
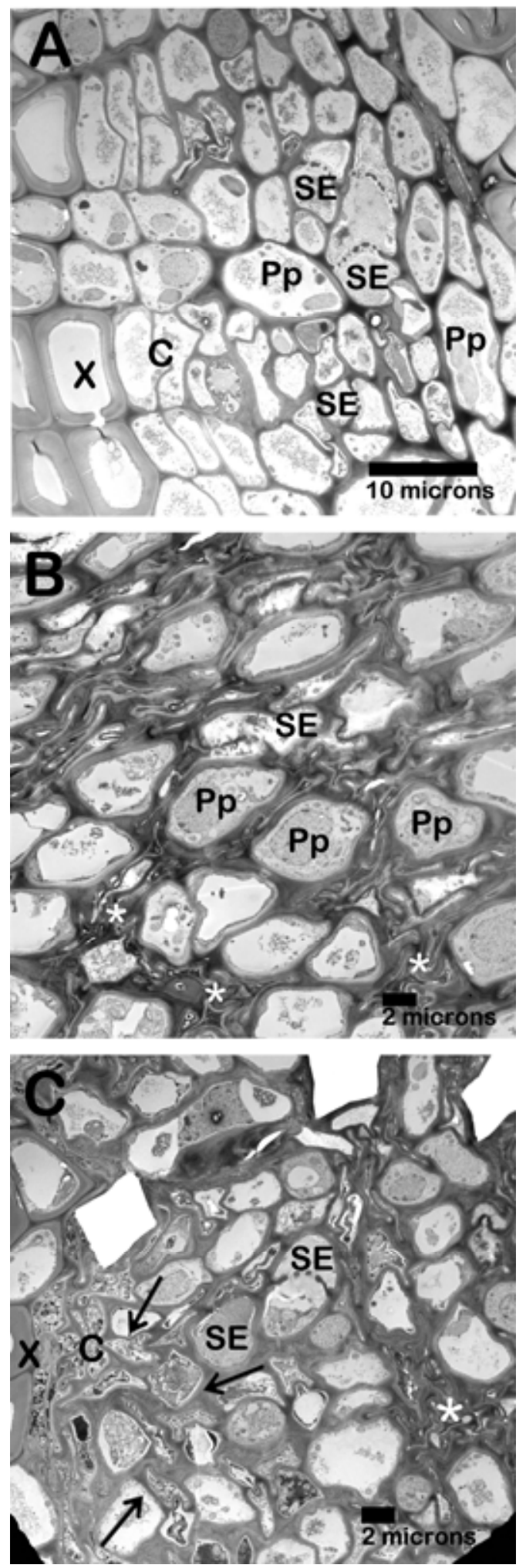

Fig. 5. Transmission electron micrographs of phloem tissue of mature leaf from A, healthy or $\mathbf{B}$ and $\mathbf{C}$, infected Madam Vinous. B, Phloem shows collapse of most of the sieve elements (SE) and companion cells (*) and nonaffected phloem parenchyma cells (Pp). C, Phloem shows necrotic cambium cells ( $\mathrm{C}$ and arrows) adjacent to xylem (X). Micrographs were taken at 6 months after inoculation of plants with 'Candidatus Liberibacter asiaticus'-infected tissue. ment. As was discussed earlier, $\approx 9$ months after inoculation, some highly symptomatic branches produced new flushes that did not show the disease symptoms at early stages of their development (Fig. 1D). Examination of leaf petiole samples taken from those young flushes showed few anatomical changes, similar to those found in tissue samples from young flushes collected at 3 months after plant inoculation (Fig. 2; data not shown). In contrast to the old symptomatic tissue of the previous flush immediately behind it, the young asymptomatic flush contained bacterial cells in a few sieve elements (Fig. 8), which correlated with our earlier findings of the bacteria in young, asymptomatic tissue at the beginning stages of infection.

\section{DISCUSSION}

Development of effective control measures for the HLB disease requires a clear understanding of interactions between the vector,
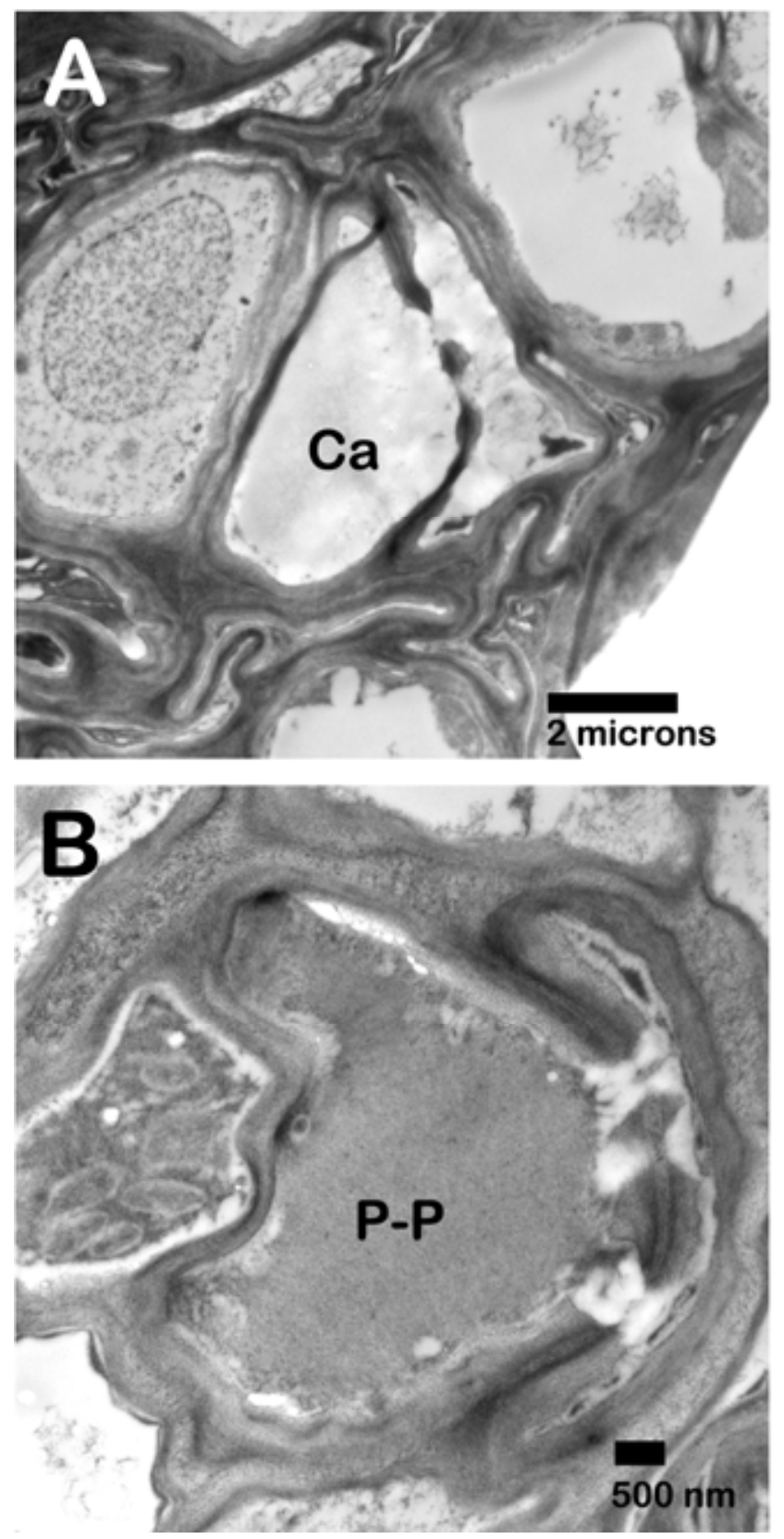

Fig. 6. Transmission electron micrographs of plugged sieve elements in phloem of infected sweet orange trees. Micrographs were taken at 6 months after inoculation of plants with 'Candidatus Liberibacter asiaticus'-infected tissue. A, Callose plug (Ca) and B, P-protein plug (P-P). 
the pathogen, and a citrus tree. However, despite extensive HLB research $(2,5)$, there is still little knowledge of how the pathogen causes disease in infected trees and when during the infection cycle it serves as an inoculum for further transmission by a psyllid vector to a new tree. One of the major obstacles for those studies is the long period of time between the infection of a tree and detection of the disease. In the greenhouse, this period is 3 to 6 months and, in the field in large trees, it may take more than a year. Thus, it is practically impossible to characterize early stages in the infection working with existing infections of field trees in which the time of infection is unknown. However, understanding of the early events in HLB infection is most critical for the development of effective methods to combat the disease. In this work, we conducted cytopathological studies by following development of the disease in citrus trees graft inoculated with ' $\mathrm{Ca}$. L. asiaticus'-containing material under greenhouse conditions with the goal of correlating ultrastructural changes and symptom production.

Based on our observations, certain anatomical aberrations occur as the disease progresses. One of the first degenerative changes induced upon invasion of the pathogen appears to be swelling of middle lamella between cell walls surrounding sieve elements. This anatomical aberration was often observed in samples from newly growing yet nonsymptomatic flushes of inoculated sweet orange and grapefruit trees at the early infection stage (3 months after inoculation). Such swelling could potentially cause compression of the confined sieve tubes noticed occasionally in some areas and, further, lead to a complete collapse and necrosis of those cells. To our knowledge, this is the first report demonstrating a change in the intercellular substance between cell walls of sieve elements occurring at the early pre-
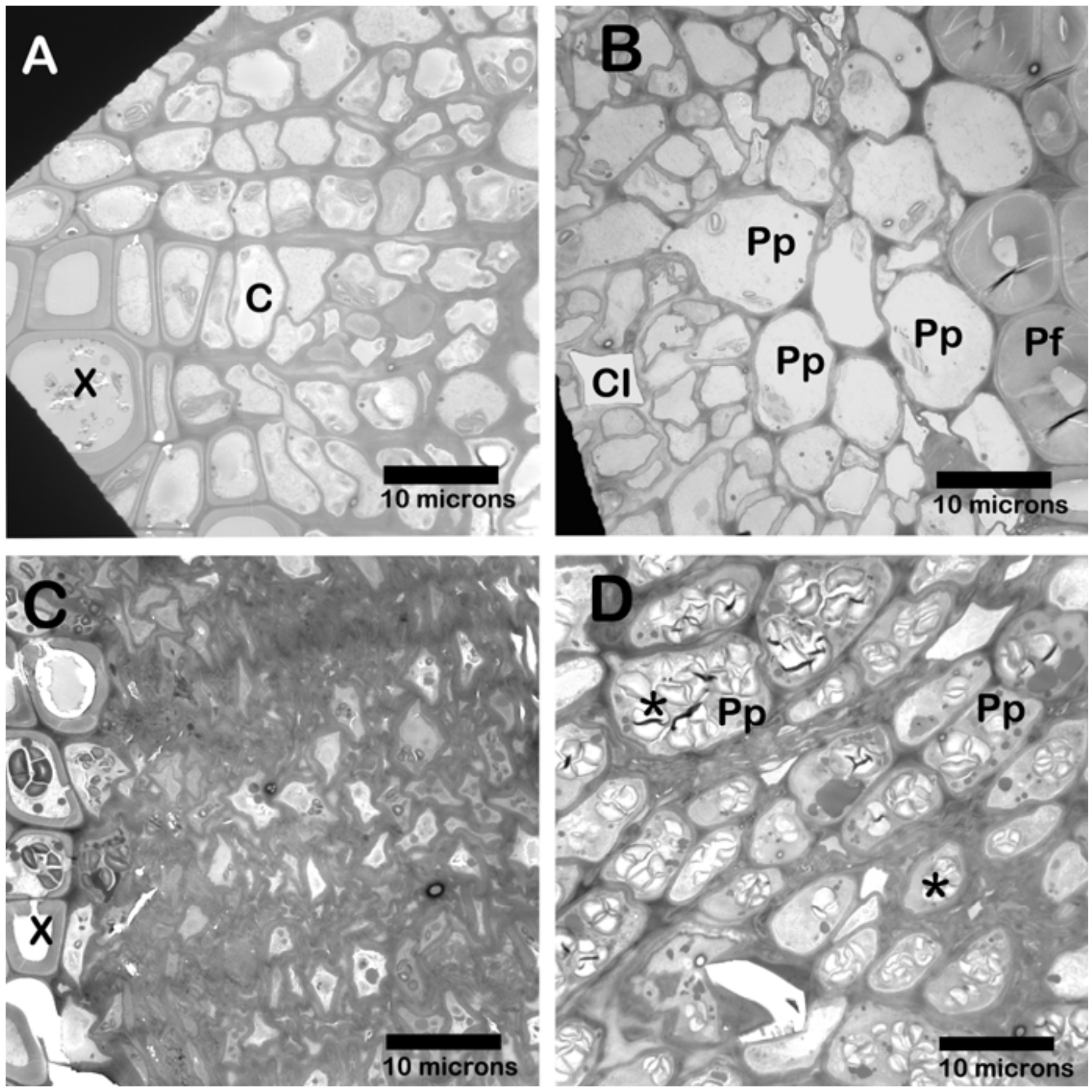

Fig. 7. Transmission electron micrographs of $\mathbf{A}$ and $\mathbf{B}$, phloem of an old, healthy leaf and $\mathbf{C}$ and $\mathbf{D}$, phloem of an old leaf from 'Candidatus Liberibacter asiaticus'-inoculated Madam Vinous at 9 months after inoculation. A and C, Area of phloem next to xylem (X); B and D, phloem next to phloem fibers (Pf). Note totally collapsed phloem that is located next to xylem in $\mathbf{C}$ and excessive starch (*) accumulated in phloem parenchyma cells (Pp) in outer phloem shown in $\mathbf{D}$. C, cambium; CI, crystal idioblast. 
symptomatic stage of HLB infection. Being likely a characteristic feature of a front line of infection, it could be easily missed in observations of tissue collected at more advanced infection stages. Development of symptoms correlated with more significant anatomical changes affecting various types of phloem cells. An increasing degree of microscopic aberrations was observed as the symptoms progressed from mild yellowing to severe chlorosis, mottling, thickening, and occasionally vein corking of leaves. Most of the anatomical changes typical for later stages of HLB infection-plugging of sieve pores with the callose-like material, necrosis of sieve elements and companion cells, and excessive starch accumulation in the phloem parenchyma cells-have been described earlier for samples from infected field trees $(1,12,22)$. What is unique in this report is that we were able to follow their progressive development.

According to previous reports, ' $\mathrm{Ca}$. Liberibacter' bacteria were not usually seen in high numbers in samples from the diseased citrus trees (2). Thus, studies on detailed characterization of the greening organism were done with samples from HLB-infected periwinkle, which is known to allow multiplication of the pathogen to quite high titers $(8,9)$. More recently, TEM observations of tissue samples from severely infected, highly symptomatic sweet orange trees by Kim et al. (12) confirmed earlier observations. They reported that, in all samples observed under electron microscope in which the bacterium was found, ' $\mathrm{Ca}$. L. asiaticus' was present in low numbers and as single cells and did not form visible aggregates. In our work, however, we found a large number of bacteria-like cells of a pleomorphic shape in several sieve elements in tissue samples of young, asymptomatic leaves from trees at an early stage of HLB infection. In contrast, we did not observe the bacteria in samples of highly symptomatic leaves collected at more advanced stages of the disease. However, bacterial cells were also visualized in tissue samples from the young consecutive flush (showing no symptoms at the time of sample collection) that grew from the old symptomatic one.

The TEM observations did not seem to be in complete agreement with the results of PCR-based tests used for detection of the HLB pathogen, which gave comparable values for samples col-

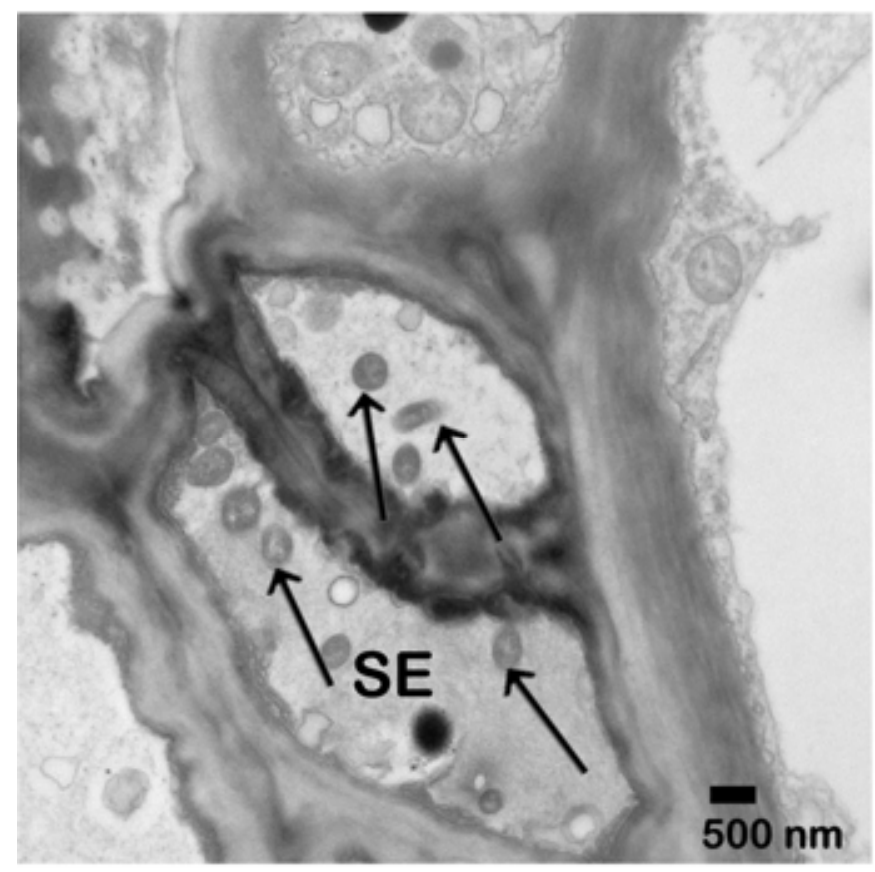

Fig. 8. Transmission electron micrographs of bacteria (arrows) in a sieve element (SE) of a young, asymptomatic leaf on a new flush growing from the old, severely affected branch. Plants were graft inoculated with 'Candidatus Liberibacter asiaticus'-infected tissue. Micrographs were taken at 9 months after inoculation. lected at different stages of the infection process. However, as it has been demonstrated, PCR-based methods do not discriminate between DNA of viable and dead bacteria (11). Because of that, qPCR, when used alone, could lead to a substantial overestimation of the presence of living organism (17). To overcome this obstacle, the approach based on qPCR carried on with the aid of ethidium monoazide, which inhibits the amplification of DNA from the dead bacterial cells, thus allowing discrimination between live and dead forms of the bacteria, has been developed $(16,19)$. Recently, Trivedi et al. (27) adapted this method to quantify viable ' $C a$. L. asiaticus' in infected citrus trees and showed that, in highly symptomatic leaf samples, a major proportion of ' $\mathrm{Ca}$. L. asiaticus' likely was present in a nonviable state. These results parallel the absence of visual bacterial cells during our TEM observations of samples from mature symptomatic branches. Presumably, the bacterial cells were embedded within completely collapsed sieve elements and, thus, could not be identified. It is possible that the majority of the bacterial population within those areas was not viable. Further observation of bacterial cells in tissue samples from the young presymptomatic flushes that emanated from the old symptomatic branches indicated that some bacteria had moved into the newly developing tissue. Thus, we can hypothesize that, for a short period of time after movement of ' $\mathrm{Ca}$. L. asiaticus' into a newly growing part of an infected tree, the majority of the pathogen population is present as live bacteria. Later, as the symptoms develop, most of the bacteria become nonviable in the symptomatic tissue. Further assays will be needed to examine composition of the pathogen population at various stages of the disease development.

One of the crucial questions for the development of HLB management strategies is when and where within a tree the bacterium serves as a better inoculum source for acquisition by psyllids. Differential results for ' $C a$. L. asiaticus' based on TEM observations in presymptomatic young, growing tissues versus older, severely affected ones may be an important clue in answering this question. We observed the highest numbers of bacteria, which likely represent a good source of the bacterium available for psyllids, in presymptomatic younger flushes. Some of our preliminary data also suggest that psyllids are able to pick up 'Ca. L. asiaticus' from infected trees months before the trees develop symptoms (W. O. Dawson, personal communication). We will continue our research on ' $\mathrm{Ca}$. L. asiaticus' distribution within infected citrus trees and how it affects psyllid transmission of the pathogen, which we anticipate will provide valuable information necessary for development of effective control measures of the disease.

\section{ACKNOWLEDGMENTS}

This research was supported by the Florida Agricultural Experiment Station and grants from USDA Cooperative State Research, Education, and Extension Service and the Florida Citrus Production Research Advisory Council. We thank C. J. Robertson and T. Shilts for excellent technical assistance; and W. O. Dawson, S. M. Garnsey, and M. S. Irey for critical reading of the manuscript.

\section{LITERATURE CITED}

1. Achor, D. S., Etxeberria, E., Wang, N., Folimonova, S. Y., Chung, K. R., and Albrigo, L. G. Sequence of anatomical symptom observations in citrus affected with Huanglongbing disease. Plant Pathol. J. 9:56-64.

2. Bové, J. M. 2006. Huanglongbing: A destructive, newly emerging, century-old disease of citrus. J. Plant Pathol. 88:7-37.

3. Bové, J. M., and Garnier, M. 1984. Citrus greening and psylla vectors of the disease in the Arabian Peninsula. Pages 109-114 in: Proc. Ninth Conf. Int. Organ. Citrus Virol. S. M. Garnsey, L. W. Timmer, and J. A. Dodds, eds. International Organization of Citrus Virologists, University of California, Riverside.

4. Chen, J., Pu, X., Deng, X., Liu, S., Li, H., and Civerolo, E. 2009. A phytoplasma related to 'Candidatus Phytoplasma asteri' detected in citrus 
showing Huanglongbing (yellow shoot disease) symptoms in Guangdong, P.R. China. Phytopathology 99:236-242.

5. da Graça, J. V. 1991. Citrus greening disease. Annu. Rev. Phytopathol. 29:109-136.

6. Folimonova, S. Y., C. J. Robertson, S. M. Garnsey, S. Gowda, and W. O. Dawson. 2009. Examination of the responses of different genotypes of citrus to Huanglongbing (citrus greening) under different conditions. Phytopathology 99:1346-1354.

7. Garnier, M, and Bové, J. M. 1977. Structure trilamellaire des deux membranes qui entourent les organismes prokaryotes associés a la maladie du "greening" des agrumes. Fruits 32:749-752.

8. Garnier, M., Danel, N., and Bové, J. M. 1984. The greening organism is a Gram negative bacterium. Pages 115-124 in: Proc. Ninth Conf. Int. Organ. Citrus Virol. S. M. Garnsey, L. W. Timmer, and J. A. Dodds, eds. International Organization of Citrus Virologists, University of California, Riverside.

9. Garnier, M., Gao, S. J., He, Y., Villechanoux, S., Gandar, J., and Bové, J. M. 1991. Study of the greening organism (GO) with monoclonal antibodies: Serological identification, morphology serotypes and purification of the GO. Pages 428-435 in: Proc. Eleventh Conf. Int. Organ. Citrus Virologists. R. H. Brlansky, R. F. Lee, and L. W. Timmer, eds. International Organization of Citrus Virologists, University of California, Riverside.

10. Halbert, S. E., and Manjunath, K. L. 2004. Asian citrus psyllids (Sternorrhycha: Psyllidae) and greening disease of citrus: a literature review and assessment of risk in Florida. Fla. Entomol. 87:330-352.

11. Josephson, K. L., C. P. Gerba, and I. L. Pepper. 1993. Polymerase chain reaction detection of nonviable bacterial pathogens. Appl. Environ. Microbiol. 59:3513-3515.

12. Kim, J. S., Sagaram, U. S., Burns, J. K., Li, J. L., and Wang, N. 2009. Response of sweet orange (Citrus sinensis) to 'Candidatus Liberibacter asiaticus' infection: microscopy and microarray analyses. Phytopathology 99:50-57.

13. Lafléche, D., and Bové J. M. 1970. Mycoplasmes dans les agrumes atteints de "greening", de "stubborn" ou de maladies similaires. Fruits 25:455-465.

14. Lafléche, D., and Bové J. M. 1970. Structures de type mycoplasme dans les feuilles d'orangers attaints de 1 maladie du greening. C. R. Acad. Sci. Ser. D 270:1915-1917.

15. Li, W., Hartung, J. S., and Levy, L. E. 2006. Quantitative real time PCR for detection and identification of 'Candidatus Liberibacter species' associated with citrus Huanglongbing. J. Microbiol. Methods 66:104-115.

16. Nocker, A., and Camper, A. K. 2006. Selective removal of DNA from dead cells of mixed bacterial communities by use of ethidium monoazide. Appl. Environ. Microbiol. 65:2122-2127.

17. Nocker, A., and Camper, A. K. 2009. Novel approaches toward preferential detection of viable cells using nucleic acid amplification techniques. FEMS Microbiol. Lett. 291:137-142.

18. Reynolds, E. S. 1963. The use of lead citrate at high $\mathrm{pH}$ as an electronopaque stain for electron microscopy. J. Cell Biol. 17:208-212.

19. Rudi, K., Moen, B., Drømtorp, S. M., and Holck, A. L. 2005. Use of ethidium monoazide and PCR in combination for quantification of viable and dead cells in complex samples. Appl. Environ. Microbiol. 71:10181024.

20. Sagaram, U. S., DeAngelis, K. M., Trivedi, P., Anderson, G. L., Lu, S. E., and Wang, N. 2009. Bacterial diversity analysis of Huanglongbing pathogen-infected citrus, using phylochip arrays and 16S rRNA gene clone library sequencing. Appl. Environ. Microbiol. 75:1566-1574.

21. Schneider, H. 1967. Phloem necrosis associated with the greening disease of sweet orange (Citrus sinensis). (Abstr.) Phytopathology 57:829.

22. Schneider, H. 1968. Anatomy of greening-diseased sweet orange shoots. Phytopathology 58:1155-1160.

23. Spurr, A. R. 1969. A low-viscosity epoxy resin embedding medium for electron microscopy. J. Ultrastruct. Res. 26:31-43.

24. Sutton, B. D., Duan, Y.-P., Halbert, S., Sun, X.-a., Schubert, T., and Dixon, W. 2005. Page H-11 in: Proc. 2nd Int. Citrus Canker Huanglongbing Res. Workshop. Florida Citrus Mutual, Orlando.

25. Tatineni, S., Sagaram, U. S., Gowda, S., Robertson, C., Dawson, W. O., Iwanami, T., and Wang, N. 2008. In planta distribution of 'Candidatus Liberibacter asiaticus' as revealed by polymerase chain reaction (PCR) and real-time PCR. Phytopathology 98:592-599.

26. Teixeira, D. C., Wulff, N. A., Martins, E. C., Kitajima, E. W., Bassanezi, R., Ayres, A. J., Eveillard, S., Saillard, C., and Bové, J. M. 2008. A phytoplasma closely related to the pigeon pea witches'-broom phytoplasma (16Sr IX) is associated with citrus Huanglongbing symptoms in the state of Sao Paulo, Brazil. Phytopathology 98:977-984.

27. Trivedi, P., Sagaram, U. S., Kim, J. -S., Brlansky, R. H., Rogers, M. E., Stelinski, L. L., Oswalt, C., and Wang, N. 2009. Quantification of viable 'Candidatus Liberibacter asiaticus' in hosts using quantitative PCR with the aid of ethidium monoazide (EMA). Eur. J. Plant Pathol. 124:553-563. 